\title{
Influence of English language in the number of citations of articles published in Brazilian journals of Ophthalmology
}

\author{
Influência do idioma inglês no número de citações de artigos publicados em periódicos brasileiros \\ de Oftalmologia
}

Rodrigo Pessoa Cavalcanti lira ${ }^{1,2}$, Rafael Marsicano Cezar Vieira ${ }^{1}$, Fauze Abdulmassih Gonçalves ${ }^{1}$, Maria Carolina Alves Ferreira ${ }^{1}$, Diana Maziero ${ }^{1}$, Thais Helena Moreira Passos ${ }^{1}$, Carlos Eduardo Leite Arieta ${ }^{1}$

\section{ABSTRACT}

Purpose: To determine the association between language and number of citations of ophthalmology articles published in Brazilian journals.

Methods: This study was a systematic review. Original articles were identified by review of documents published at the two Brazilian ophthalmology journals indexed at Science Citation Index Expanded - SCIE ["Arquivos Brasileiros de Oftalmologia (ABO)"and"Revista Brasileira de Oftalmologia (RBO)"]. All document types ("articles" and "reviews") listed at SCIE in English (English Group) or in Portuguese (Portuquese Group) from January 1, 2008 to December 31, 2009 were included, except: "editorial materials"; "corrections"; "letters"; and "biographical items". The primary outcome was the number of citations through the end of second year after publication date. Subgroup analysis included likelihood of citation (cited at least once versus no citation), journal, and year of publication.

Results: The search at the web of science revealed 382 articles [107 (28\%) in the English Group and 275 (72\%) in the Portuguese Group]. Of those, 297 (77.7\%) were published at the $\mathrm{ABO}$ and $85(23.3 \%)$ at the RBO. The citation counts were statistically significantly higher $(P<0.001)$ in the English Group $(1.51$ - SD 1.98 range 0 to 11) compared with the Portuguese Group (0.57 - SD 1.06 - range 0 to 7). The likelihood citation was statistically significant higher $(P<0.001)$ in the English Group (70/107 - 65.4\%) compared with the Portuguese Group (89/275 - 32.7\%). There were more articles published in English at the ABO (98/297 - 32.9\%) than at the RBO $(9 / 85-10.6 \%)[P<0.001]$. There were no significant difference $(P=0.967)$ at the proportion of articles published in English at the years 2008 (48/172 - 27.9\%) and $2009(59 / 210-28.1 \%)$.

Conclusion: The number of citations of articles published in Portuguese at Brazilian ophthalmology journals is lower than the published in English. The results of this study suggest that the editorial boards should strongly encourage the authors to adopt English as the main language in their future articles.

Keywords: Language; Ophthalmology; Bibliometrics; Publication for scientific diffusion; Scientific and technical publications; Journal impact factor; Journal article

\section{RESUMO}

Objetivo: Determinar a associação entre a língua e o número de citações de artigos publicados em periódicos de oftalmologia brasileiros.

Métodos: Este estudo foi uma revisão sistemática. Artigos originais foram identificados a partir da revisão dos documentos publicados nos dois periódicos de oftalmologia brasileiros indexados no Science Citation Index Expanded - SCIE ["Arquivos Brasileiros de Oftalmologia $(A B O)^{\prime \prime}$ e "Revista Brasileira de Oftalmologia (RBO)"]. Todos os tipos de documentos ("artigos" e "revisões") listados no SCIE em inglês (Grupo Inglês) ou em português (Grupo Português), de 1ํde janeiro de 2008 a 31 de dezembro de 2009 foram incluídos, exceto: "editoriais"; "correções"; "cartas"; e "biografias". O desfecho primário foi o número de citações até o segundo ano após a data de publicação. Análise de subgrupo incluiu probabilidade de citação (citado pelo menos uma vez contra nenhuma citação), periódico e ano da publicação.

Resultados: A pesquisa na Web of Science revelou 382 artigos [107 (28\%) no Grupo Inglês e 275 (72\%) no Grupo Português]. Destes, 297 (77,7\%) foram publicados na ABO e 85 (23,3\%) na RBO. O número de citações foi significativamente maior $(P<0,001)$ no Grupo de Inglês (1,51-DP 1,98-faixa 0 to 11) em comparação com o Grupo Português (0,57-DP 1,06 - faixa 0 to 7). A probabilidade de citação foi estatisticamente superior $(P<0,001)$ no Grupo de Inglês $(70 / 107$ - 65,4\%) comparado com o Grupo Português (89/275 - 32,7\%). Havia mais artigos publicados em Inglês na ABO (98/297 - 32,9\%) do que no $R B O(9 / 85-10,6 \%)[P<0,001]$. Não houve diferença significativa $(P=0,967)$ na proporção de artigos publicados em Inglês nos anos de 2008 (48/172 - 27,9\%) e 2009 (59/210 - 28,1\%).

Conclusão: O número de citações de artigos publicados em Português em periódicos brasileiros de oftalmologia é menor do que o publicado em Inglês. Os resultados deste estudo sugerem que os conselhos editoriais devem incentivar fortemente os autores a adotar o Inglês como língua principal em seus artigos futuros.

Descritores: Linguagem; Oftalmologia; Bibliometria; Publicações de divulgação científica; Publicações científicas e técnicas; Fator de impacto de revistas; Artigo de revista

\section{INTRODUCTION}

The vast majority of research articles are published in English ${ }^{(1)}$. Journals of non-English speaking countries have adopted English as their official language ${ }^{(2,3)}$. Only a minority of scientific journals publishes their articles in other languages such as German, French, Japanese, Chinese, Spanish or Portuguese. Due to language restrictions, only a minority of researchers read these articles, therefore these articles are rarely cited. English-language journals appear to have greater visibility, and hence, impact factors, than their non-English counterparts ${ }^{(4-6)}$.

The impact factor measures journal's visibility and it is a method to rank journals by citation analysis; i.e., the more frequently a given journal's articles are cited, the higher the journal's impact factor. The interests in a journal's impact factor are many-fold. Authors consider the impact factor prior to submitting an article to a particular journal. More submissions allow a superior selection of articles. Faculty

Physician, Department of Ophthalmology, Universidade Estadual de Campinas, Campinas, SP, Brazil. 
committees involved in promotions or search of new members rely heavily on impact factors, as do scientific boards of granting institutions, especially in Europe and South America. Publishers observe the impact factors of their journals (in addition to circulation numbers and incomes from advertisements) ${ }^{(7)}$. However, it is important to emphasize that the clinical impact of a research - how much that study has contributed to improve the clinical practice - may not be related to citation indexes ${ }^{(8)}$.

In Brazil, between 1986 and 2000, the most popular ophthalmology journal published only 4.6\% of articles in English ${ }^{(9)}$.

To the best of our knowledge, the impact of publication language on citation frequency in the ophthalmology journals has not yet been investigated from a Brazilian perspective. In the present study, we focused on papers published between 2008 and 2009. The main purpose of this study was to determine the associations between language and number of citations of ophthalmology articles published in Brazilians journals.

\section{METHODS}

This study was a systematic review. Original articles were identified by review of documents published at the two Brazilian ophthalmology journals indexed at Science Citation Index Expanded - SCIE ["Arquivos Brasileiros de Oftalmologia $(\mathrm{ABO})$ " and "Revista Brasileira de Oftalmologia (RBO)"]. All document types ("articles"and "reviews") listed at SCIE in English (English Group) or in Portuguese (Portuguese Group) from January 1, 2008 to December 31, 2009 were included, except: "editorial materials"; "corrections"; "letters"; and "biographical items".

The primary outcome was the number of citations through the end of the second year after publication date. Most articles are rarely cited, if at all, during the same year in which they were published, but the citation count of the 2 subsequent years is representative (it forms the basis of estimating journal impact factors). Subgroup analysis included likelihood of citation (cited at least once versus no citation), journal, and year of publication.

To estimate the citation frequency of research articles included in our study, we accessed the Institute for Scientific Information (ISI) Web of Science database ${ }^{(10)}$. The Web of Science search strategies was: (publication name) "Arquivos Brasileiros de Oftalmologia OR Revista Brasileira de Oftalmologia"; (year of publication) "2008-2009"; (timespan) date range to articles published in 2008, "from 2008-01-01 to 2010-12-31", and date range to articles published in 2009, from "2009-01-01 to 2011-12-31"; and (citation database) "Science Citation Index Expanded.

Descriptive statistics were calculated. Continuous data were expressed as mean values, standard deviation (SD) and ranges. Between-group differences of continuous and categorical variables were compared using Mann Whitney U Test or Pearson chi-square test where appropriate. Analyses were conducted using PSPP statistical software. P values are 2-tailed. Statistical significance was considered at the 0.5 level.

\section{RESULTS}

The search at the web of science revealed 382 articles [107 (28\%) in the English Group and 275 (72\%) in the Portuguese Group]. Of those, 297 (77.7\%) were published at the $\mathrm{ABO}$ and 85 (23.3\%) at the RBO.

The citation counts were statistically significantly higher $(P<0.001)$ in the English Group (1.51 - SD 1.98 - range 0 to 11) compared with the Portuguese Group (0.57 - SD 1.06 - range 0 to 7) [Figure 1]. The likelihood citation was statistically significantly higher $(\mathrm{P}<0.001)$ in the English Group (70/107 - 65.4\%) compared with the Portuguese Group (89/275 - 32.7\%).

There were more articles published in English at the ABO (98/297 $32.9 \%)$ than at the RBO $(9 / 85-10.6 \%)[P<0.001]$. The citation counts were statistically significant higher $(P<0.001)$ at the $A B O(0.99$ - SD 1.56 -

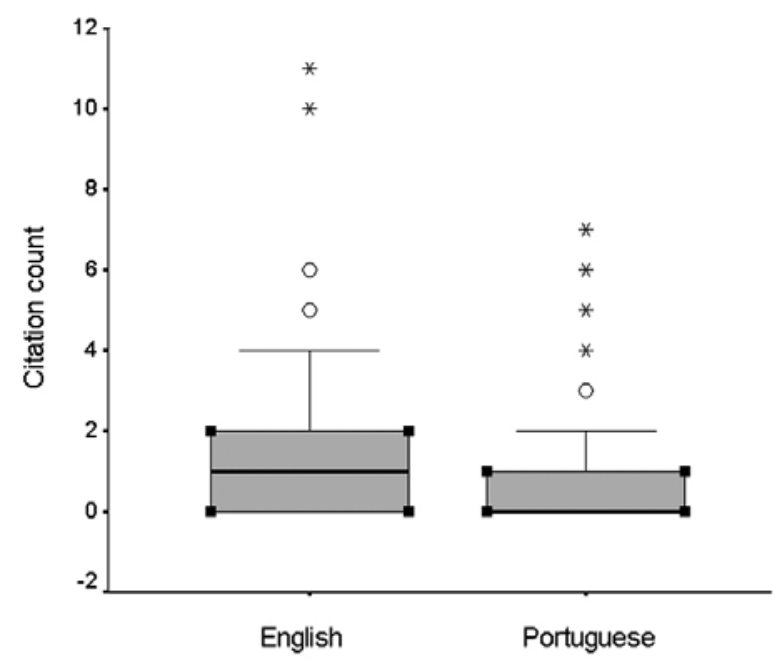

Figure 1. Language vs. citations count on articles published in Brazilians journals of Ophthalmology, 2008-2009.

range 0 to 11) compared with the RBO (0.29 - SD 0.63 - range 0 to 3). The likelihood citation was statistically significant higher $(\mathrm{P}<0.001)$ at the $\mathrm{ABO}(140 / 297-47.1 \%)$ compared with the RBO (18/85 - 21.2\%).

There were no significant differences $(\mathrm{P}=0.967)$ at the proportion of articles published in English at the years 2008 (48/172 - 27.9\%) and 2009 (59/210 - 28.1\%).

\section{DISCUSSION}

The results of this study demonstrated that the number of and the likelihood of citation of an article (cited at least once versus no citation) published in Portuguese in Brazilian ophthalmology journals are lower than the published in English. In others studies to determine the association between journal country of origin and language and journal impact factor of general medicine journals, the authors concluded that journal impact factor is more associated with journal language, independently of journal impact factor, number of authors, topic, or country of origin ${ }^{(11,12)}$.

These results stress the importance of English as actual's scientific language ${ }^{(5)}$. German and French, important languages since the $19^{\text {th }}$ century, as others languages like Portuguese, Chinese, Japanese, and Spanish, have suffered a steep decline after World War $\|^{(1,4)}$, since then, journals of non-English countries have adopted the English language ${ }^{(13)}$

The number of times an article is cited over a given time period might indicate the level of importance attributed to its findings by research medical community. It was not a primary purpose of this study to compare the $\mathrm{ABO}$ and the $\mathrm{RBO}$, but the results demonstrated that the articles of the $A B O$ have been significantly more cited. One of the main reasons probably is because $A B O$ has published more articles in English. Although the percentage of articles in English did not increase between 2008 and 2009 in both journals, some editorial changes have been implemented after 2010 and may interfere in the percentage of English-written manuscripts.

Authors may question that accepting submissions only in English ${ }^{(3,14)}$ would prevent some readers, who do not master the English language, to be updated. However, the intention of the Brazilian editors should be that national scientific journals remain alive and active, seeking to stimulate and encourage doctors to improve their publications ${ }^{(15-17)}$. Considering that what may promote a journal is the number of citations generated, and for this to occur, besides the quality of the research published therein, is its visibility, we must bow to the global trend that English is the official language of international 
conferences, publications and communications in general ${ }^{(3)}$. It is not enough to publish abstracts and keywords in English. It is essential that the whole text to be published in English, otherwise it certainly should not be read or even mentioned. If we verify the references of any article we will realize that most are published in English.

The results of this study suggest that the editorial boards should strongly encourage the authors to adopt English as the main language in their future articles. This effort may contribute to the improvement of Brazilians Ophthalmology journals impact factor.

\section{REFERENCES}

1. Winkmann G, Schlutius S, Schweim HG. [Publication languages of impact factor journals and of medical bibliographic databanks]. Dtsch Med Wochenschr. 2002; 127(4):131-7. German. Comment in Dtsch Med Wochenschr. 2002;127(4):129-30.

2. Schaffner A, Gehr P, Perruchoud A, Straub W, Suter P, von Segesser L. Welcome editorial. Swiss Med Wkly. 2001;131:3

3. Viebig RG, Pardini F. O inglês é preciso. Arq Gastroenterol. 2009;46(3):162-3.

4. Winkmann G, Schlutius S, Schweim HG. [Citation rates of medical German-language journals in English-language papers - do they correlate with the Impact Factor, and who cites?]. Dtsch Med Wochenschr. 2002;127(4):138-43. German.

5. Bakewell D. Publish in english, or perish? Nature. 1992;356(6371):648

6. Borsuk RM, Budden AE, Leimu R, Aarssen LW, Lortie CJ. The influence of author gender, national language and number of authors on citation rate in ecology. Open Ecol J. 2009;2(1):25-8
7. Schaffner A. Journal impact factors depend on more than just publication language Swiss Med Wkly. 2006;136(27-28):411-2.

8. Campanatti-Ostiz H, Andrade CR. Periódicos nacionais em fonoaudiologia: caracterização de indicador de impacto. Pró-Fono. 2006;18(1):99-110.

9. Ventura AG, Ventura AJ, Santos SA. Características evolutivas dos artigos científicos publicados nos Arquivos Brasileiros de Oftalmologia entre os anos de 1986 e 2000 Arq Bras Oftalmol. 2008;71(5):711-6.

10. Thomson Reuters. Web of Knowledge [v.5.7] - Web of Science Home [Internet]. [cited 2012 Aug 28]. Available from: http://apps.webofknowledge.com/ WOS_GeneralSearch_input.do?highlighted_tab=WOS\&product=WOS\&last_prod= WOS\&SID=4DE1 fee@PiabfLIcgJc\&search_mode=GeneralSearch

11. Mueller PS, Murali NS, Cha SS, Erwin PF, Ghosh AK, others. The association between impact factors and language of general internal medicine journals. Swiss Med Wkly. 2006;136(27-28):441-3.

12. Poomkottayil D, Bornstein M, Sendi P. Lost in translation: the impact of publication language on citation frequency in the scientific dental literature. Swiss Med Wkly. 2011;141:w13148.

13. Indian Journal of Ophthalmology. Instructions for contributors [Internet]. [cited 2012 Aug 28]. Available from: http://www.ijo.in/contributors.asp

14. Muccioli C, Campos M, Goldchmit M, Dantas PE, Bechara SJ, Costa VP. Artigos em inglês nos Arquivos Brasileiros de Oftalmologia: um resultado da globalização. Arq Bras Oftalmol. 2006;69(4):461.

15. Chamon W, Melo Jr LA. Impact factor and insertion of the ABO in the world scientific literature. Arq Bras Oftalmol. 2011;74(4):241-2.

16. Rocha EM. Uma boa fase para a internacionalização da pesquisa biomédica brasileira. Arq Bras Oftalmol. 2011;74(6):391-2

17. Portes AJ. A RBO na era da informação digital. Rev Bras Oftalmol. 2011;70(1):5-6 